\title{
Beetles as Plant Pathogen Vectors
}

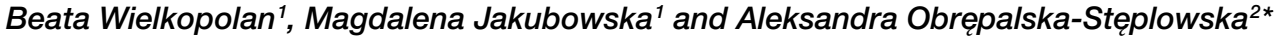 \\ ${ }^{1}$ Department of Monitoring and Signaling of Agrophages, Institute of Plant Protection - National Research Institute, Poznan', \\ Poland, ${ }^{2}$ Department of Molecular Biology and Biotechnology, Institute of Plant Protection - National Research Institute, \\ Poznań, Poland
}

OPEN ACCESS

Edited by:

Bing Yang,

Sichuan Academy of Giant Panda,

China

Reviewed by:

Lilin Zhao,

Institute of Zoology, Chinese

Academy of Sciences (CAS), China

Ying Zhang,

Yunnan University, China

*Correspondence:

Aleksandra Obrępalska-Stęplowska olaob@o2.pl

Specialty section:

This article was submitted to Plant Pathogen Interactions,

a section of the journal

Frontiers in Plant Science

Received: 28 July 2021

Accepted: 15 September 2021

Published: 11 October 2021

Citation:

Wielkopolan B, Jakubowska M and

Obrępalska-Stęplowska A (2021)

Beetles as Plant Pathogen Vectors.

Front. Plant Sci. 12:748093.

doi: 10.3389/fpls.2021.748093
Herbivorous insects, likewise, other organisms, are exposed to diverse communities of microbes from the surrounding environment. Insects and microorganisms associated with them share a range of relationships, including symbiotic and pathogenic. Insects damage plants by feeding on them and delivering plant pathogens to wounded places, from where pathogens spread over the plant. Thus insects can be considered as both pests and reservoirs or vectors of plant pathogens. Although beetles are not mentioned in the first place as plant pathogen vectors, their transmission of pathogens also takes place and affects the ecosystem. Here we present an overview of beetles as vectors of plant pathogens, including viruses, bacteria, fungi, nematodes, and Oomycota, which are responsible for developing plant diseases that can have a significant impact on crop yield and quality.

Keywords: beetles, vector, plant pathogens, Coleoptera, viruses, bacteria, fungi, plant diseases

\section{INTRODUCTION}

Herbivorous insects, likewise, other organisms, are exposed to diverse communities of microbes, including bacteria, fungi, viruses, Oomycota, from the surrounding environment (Hammer et al., 2017; Gurung et al., 2019). Many microbes acquired by insects via the diet or soil may not impact insect hosts (Hammer et al., 2017; Zhao et al., 2019). However, some can colonize insects and share with them symbiotic (mutualism, commensalism, and parasitism) or pathogenic relationships. Insects-associated microbes can have diverse roles in mediating insect interactions with plants, other insects, or other microbes (Chung et al., 2013; Mason et al., 2019). It has been shown that insect's oral secretions or regurgitants contain diverse microbial communities, effectors, proteins, and small molecules that can affect plant defense response to insect feeding (Figure 1; Acevedo et al., 2017; Gedling et al., 2018).

Insects can be considered as both pests and reservoirs or even vectors of plant pathogens because they damage the plant directly by feeding and indirectly by delivering plant pathogens to wounded places, from where pathogens spread throughout the plant (Figure 1; Agrios, 2008).

Hemipteran insects, including leafhoppers and psyllids, are considered by far the most important vectors of bacteria (Perilla-Henao and Casteel, 2016) due to their wide host range and rapid reproduction. In turn, whiteflies and aphids are considered important vectors of viruses (Jones, 2003; Perilla-Henao and Casteel, 2016; Ghosh et al., 2017). 


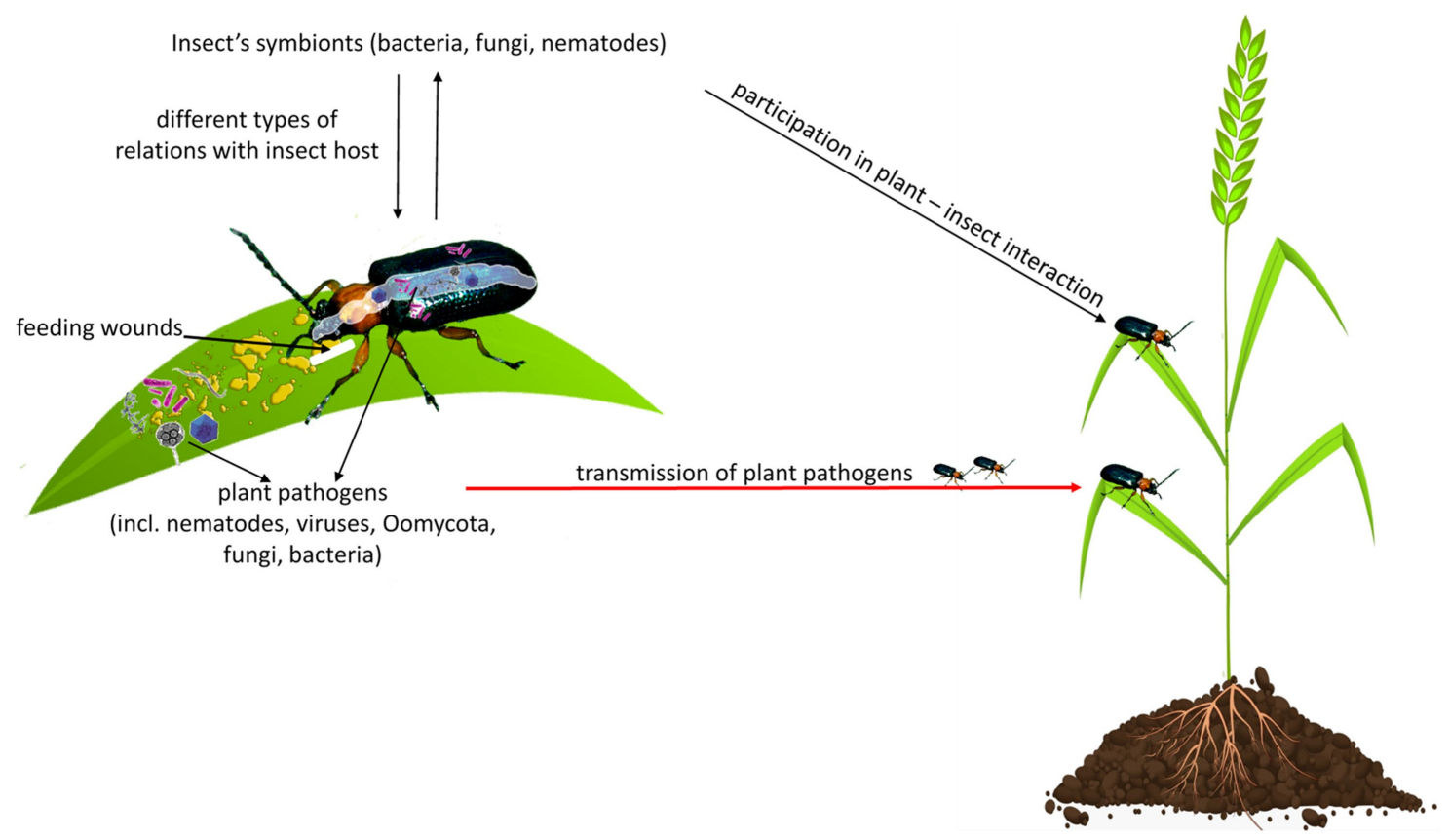

FIGURE 1 | Herbivorous insects are exposed to diverse communities of microbes, including bacteria, fungi, viruses, Oomycota, or nematodes. They share with insects different types of relationships, including symbiotic (mutualism, commensalism, and parasitism) or pathogenic. An insect can damage a plant directly by feeding and indirectly by the transmission of plant pathogens to a wounded place, from where pathogens spread throughout the plant. Insect's oral secretion or regurgitant may contain microbes that can affect plant response to insect feeding or can be pathogenic for the plant.

Coleoptera is the largest insect order accounting for over 360,000 species, which constitutes $40 \%$ of the known insect species in the world. Beetles are not mentioned in the first place as disease vectors, but some of them cause considerable damages through the transmission of plant pathogens. Here, we present an overview of beetles as vectors of plant pathogens, including viruses, bacteria, nematodes, fungi, and Oomycota, which are responsible for developing plant diseases with a significant impact on crop yield, and quality (Salaau Rojas, 2013; Pan et al., 2018). The successful management of plant diseases requires knowledge on the plant-pathogen-insect vector interactions which is fundamental to reduce the occurrence and spread of the plant diseases, and to limit yield losses as well as the amount of used plant protection chemistry which is very important for the environment.

\section{MECHANISM OF PLANT PATHOGENS TRANSMISSION}

Plants are rooted and motionless, and thus the pathogen must be delivered to them (Agrios, 2008). Natural plant openings or wounds are necessary for the pathogen to penetrate the plant. Insects are considered part of the disease complex because feeding wounds constitute the point of entry for plant pathogens (Willsey et al., 2017). Insects are frequently involved in the transmission of plant pathogens from one plant or organ to another. The way of transmission depends on both, the insect species, and pathogens. In some cases, insects carry pathogens incidentally, without any special relationship between them. For instance, the bacterial and fungal spores are often sticky and cling to the insect's body during feeding or walking through a plant area where pathogens are deposited. The insect can also acquire the pathogen with food. Ingested pathogen circulates within the insect body, reaches the salivary glands, mouthparts, and finally enters the plant host through the wounds resulting from insect feeding. Overall, insects can carry plant pathogens externally on their legs, mouthparts, bodies, and internally in their digestive tract, and hemocoel (Figure 2; Agrios, 2008; Gedling et al., 2018).

Insects select plant hosts based on the number of sensory cues including visual (e.g., leaf color), olfactory (emission of volatile organic compounds - VOCs; Heard, 1999; Mauck et al., 2014), gustatory, or tactile stimuli (Heard, 1999). Numerous studies suggest that plant pathogens, including viruses, induce changes in plant phenotypes, their palatability, and nutrients components, to enhance visiting of the plants by insect vectors and to increase pathogens acquisition and transmission to other plants (Lieutier et al., 2009; Chesnais et al., 2020). It was reported that beetle vectors have a preference for pathogeninfected plants (Musser et al., 2003). For instance, the induction of changes in the plant VOCs enhances the aggregation of insect vectors on infected plants (Mauck et al., 2010). This phenomenon is observed in many insect species, including these belonging to the Coleoptera order. Pathogens can also affect the quality of the primary plant host as the resource for the insect vector (Mauck et al., 2010; Chesnais et al., 2019) and can have a direct effect on insect behavior (Figure 2; Coplin et al., 2002; Mann et al., 2012; Shapiro et al., 2012). 


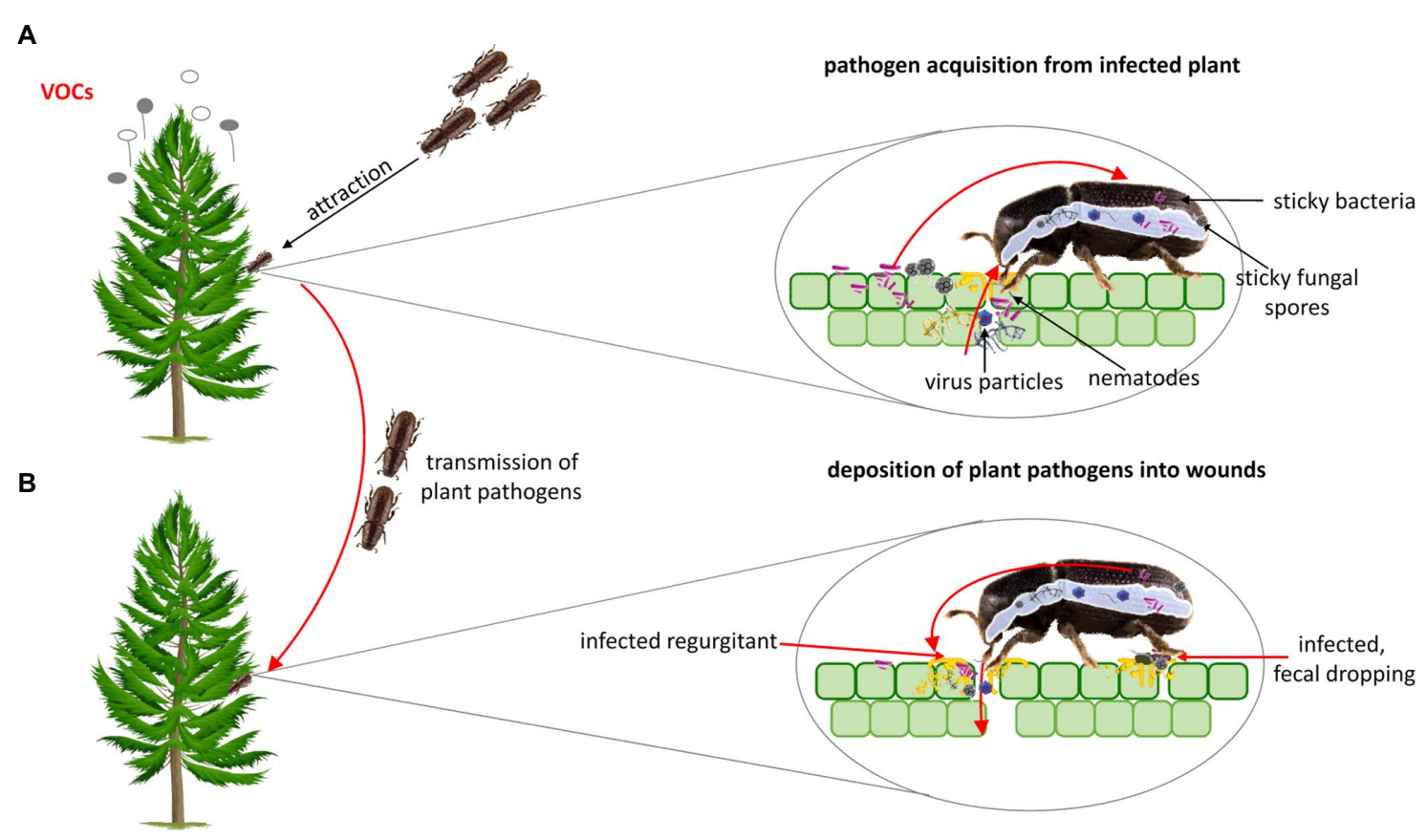

FIGURE 2 | (A) Plant pathogens can enhance their acquisition and transmission through altering plant volatile organic compounds (VOCs) that attract insect vector to infected plants. In some cases both the larval and imago stage may be involved in the transmission of plant pathogens. Beetles can acquire plant pathogens incidentally (the bacterial and fungal spores are often sticky and cling to the insect's body) and with food. (B) Ingested pathogen circulates through/within the insect body, reaches the salivary glands, mouthparts, and finally enters plant host through the wounds resulting from insect feeding. Some pathogens can be deposited into wounded place through faecal dropping.

In addition, the increased attraction of insect vectors to infected plant hosts has been documented in response to visual changes in plant phenotype elicited by plant pathogens (Chesnais et al., 2020). Musser et al. (2003) indicated that Epilachna varivestis (Coccinellidae) prefers to feed on visually changed plants infected by bean pod mottle virus (BPMV, Secoviridae) and southern bean mosaic virus (SBMV, Solemoviridae).

\section{BEETLES AS RESERVOIRS AND VECTORS OF VIRUSES}

Several plant viruses are spread by plant contact or their vegetative reproduction, but many of them depend on vectors. More than 70 species of beetles (Smith et al., 2017) are known to transmit viruses that infect economically important vegetables and grain crops. It is estimated that beetles transmit approximately $11 \%$ of insect-borne viruses (Smith et al., 2017; Bhat and Rao, 2020). Beetle vectors of plant viruses belong to Chrysomelidae, Coccinellidae, Curculionidae, Meloidae families (Gergerich, 2001; Fereres and Raccah, 2015) and have a unique mode of transmission of at least six groups of plant virus genera: Machlomovirus, Bromovirus, Carmovirus, Comovirus, Sobemovirus, and Tymovirus (Scott and Fulton, 1978; Gedling et al., 2018). Mechanisms of virus acquisition and transmission are associated with the fact that most of the beetle vectors eat plant cells between the leaf veins and regurgitate during feeding, bathing their mouthparts with sap and virus particles, therefore beetle-associated viruses can be deposited into a chewing wound. Virus particles are translocated in the xylem elements to parts of the plants away from the site where they were deposited by an insect (Gergerich and Scott, 1988, 1991; Gedling et al., 2018).

Noncirculative viruses can be transmitted in a semipersistent manner by many groups of insects including beetles (Raccah and Fereres, 2009). These viruses are retained in the foregut, a chitinous anterior region of the insect alimentary canal (Mauck et al., 2018). Some viruses move into the beetle hemolymph immediately after ingestion (Fereres and Raccah, 2015), wherein probably virus is retained for extended periods (Fulton and Scott, 1977; Scott and Fulton, 1978). It was indicated that a beetle could get viruses after a single bite of plant tissue, but the efficiency of acquisition increases with more extensive feeding (Fulton and Scott, 1977). Beetles can acquire and transmit the virus after feeding for a few seconds and can retain the virus from 1 to 10 days (Agrios, 2008), depending on the beetle species. For instance, E. varivestis retains cowpea severe mosaic virus (CPSMV, Secoviridae) for 1 day, whereas Cerotoma trifurcate (Chrysomelidae) retains the same virus for several days (Fereres and Raccah, 2015), and in turn, Diabrotica balteata (Chrysomelidae) vectors bean rugose mosaic virus (BRMV, Secoviridae; Table 1) for 3 days (Fulton and Scott, 1977).

Adult beetles and, in some cases, also larvae are very important vectors of plant viruses (Table 1). Nault (1978) found that larvae of Oulema melanopus (Chrysomelidae) transmitted 
TABLE 1 | Beetle vectors of plant pathogens and their plant hosts.

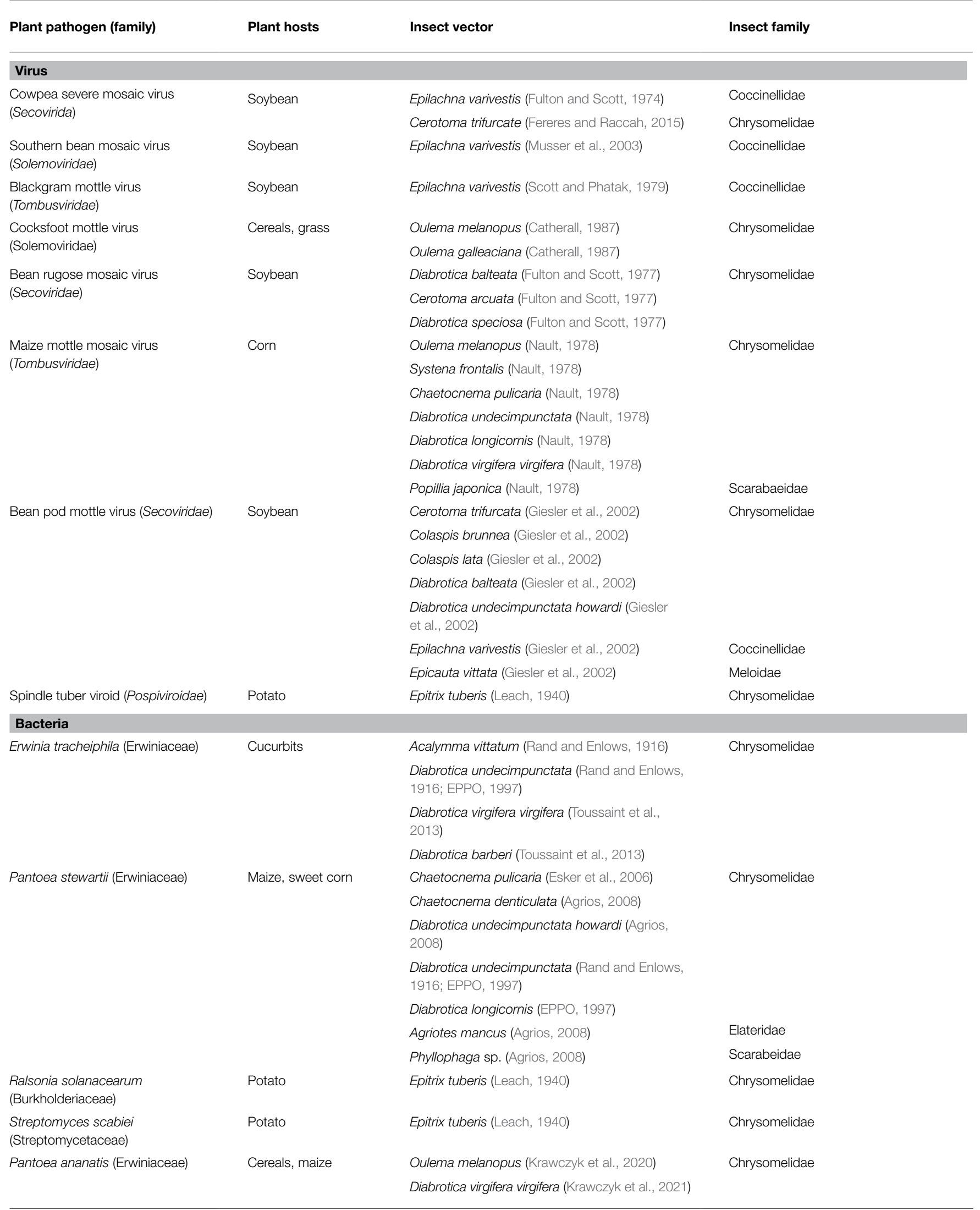


TABLE 1 | Continued

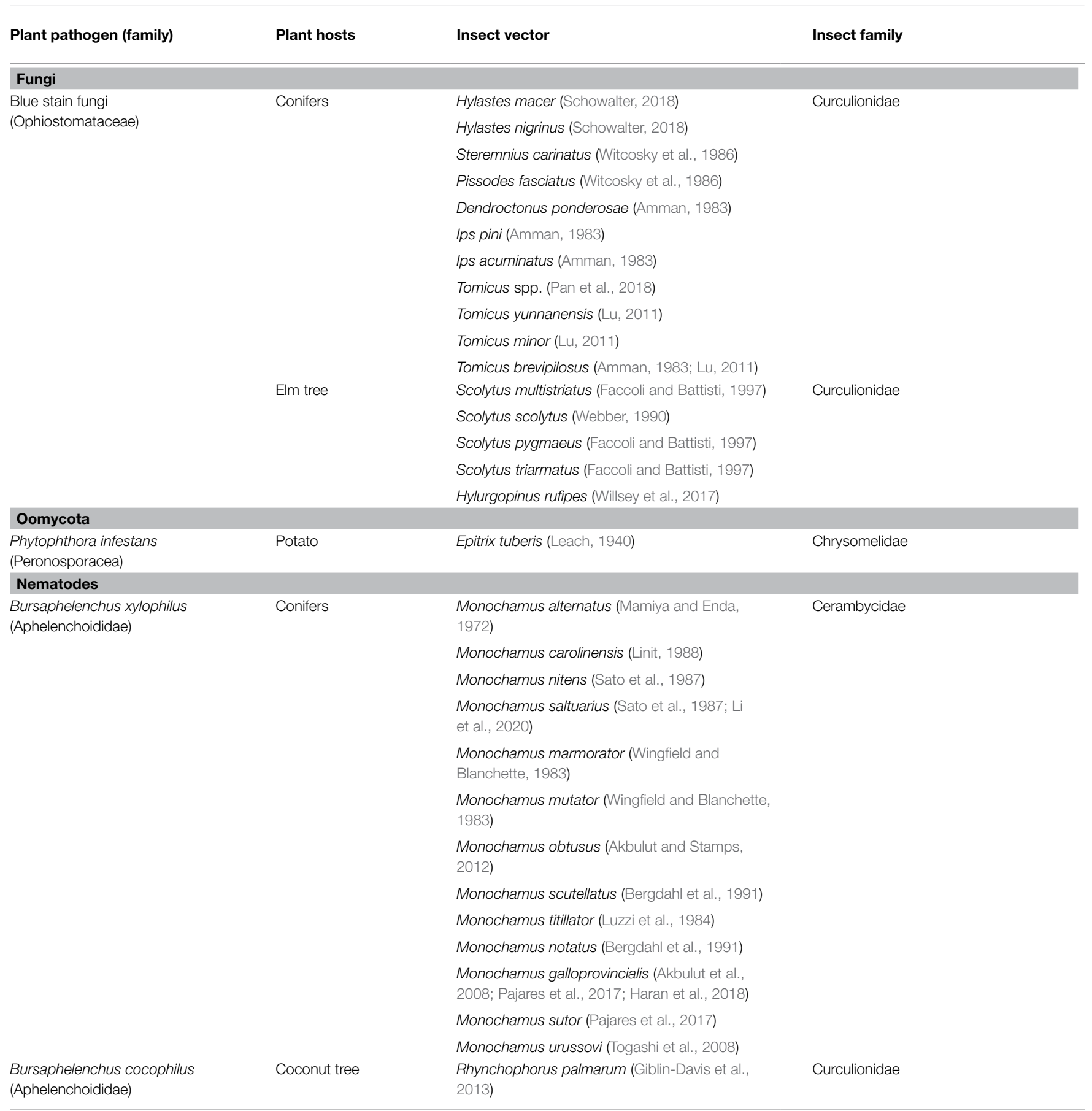

maize chlorotic mottle virus (MCMV, Tombusviridae) more efficiently in comparison with adults (Nault, 1978). Additionally, O. melanopus, as well as Oulema gallaeciana (Chrysomelidae), can transmit effectively cocksfoot mottle virus (CfMV, Solemoviridae; Catherall, 1987; Table 1) for up to 15 days after its acquisition. CfMV is transmitted more efficiently by adults than in the larval stage.

BPMV, a widespread pathogen in the major soybean-growing areas, can be effectively transmitted by several species of the
Chrysomelidae family (Table 1; Giesler et al., 2002). BPMV infection can lead to yield reduction and a deterioration in the quality of the soybean seeds. Reduction of crop yield depends on the time of virus infection relative to plant development (Gergerich and Scott, 1996; Gergerich, 1999) and can range between 36 and 52\% (Hopkins and Mueller, 1984).

Epilachna varivestis is considered to be a severe pest among others of soybean (Fan et al., 1992; Nakamura and Chavez, 2007). Gedling et al. (2018) showed that E. varivestis regurgitant 
is fundamental to the specificity of beetle transmissible viruses. This pest can transmit several plant viruses, including cowpea severe mosaic (CPMV, Secoviridae; Fulton and Scott, 1974), SBMV (Musser et al., 2003), or blackgram mottle virus (BMoV, Tombusviridae; Scott and Fulton, 1978; Scott and Phatak, 1979; Table 1).

\section{BACTERIAL TRANSMISSION}

Plant bacterial disease can be manifested by several types of symptoms, including blights, galls, and soft rots. Bacteria can be present on the plant surface in droplets and sticky exudates released through cracks, wounds in the infected area, or through natural openings (including stomata, nectar rhodes, and hydathodes). Insects can be attracted by sweet bacterial exudates. During insect feeding, bacteria stick to mouthparts and other parts of the insect body (Agrios, 2008). Some bacteria obtained with plant material migrate to the insect gut epithelium and are deposited on wounds through infected fecal droppings (Mitchell and Hanks, 2009; Figure 2). For the development of a new bacterial infection, a fresh wound or the natural opening and enough moisture in the plant surface are needed. Thanks to this, bacteria multiply and move into the plant, and bacterial infection is developing (Agrios, 2008).

There are much more currently known and described beetles as vectors of viruses and fungal pathogens than beetles that transmit bacterial pathogens. However, metagenomic studies, including microbiome analyses, may soon provide a lot of valuable information about beetles as reservoirs or even vectors of other plant pathogenic bacteria.

\section{Bacterial Wilt of Cucurbits}

Erwinia tracheiphila (Erwiniaceae) causes wilt of cucurbits (Rojas et al., 2011), which can be responsible for millions of dollars yield losses and additional costs spent on indirect preventative measures (Shapiro et al., 2014). Bacterial wilt is dangerous for many cucurbit crops, causing losses of up to $80 \%$ (Rojas et al., 2011). Erwinia tracheiphila is unable to infect the cucurbits through the natural openings of the plants such as stomates or hydathodes, thus wounding, including those caused by insects is needed for pathogen entry and developing the disease (Ferreira and Boley, 1992). Two species of the Chrysomelidae family: Acalymma vittatum and Diabrotica undecimpunctata (Stephenson et al., 2004; Du et al., 2008; Sasu et al., 2010) are involved in the spreading of E. tracheiphila (Table 1). Toussaint et al. (2013) indicated that Diabrotica virgifera virgifera and Diabrotica barberi (Chrysomelidae) might also be involved in the transmission of this pathogen (Table 1). Beetles acquire this bacterium during feeding on infected cucurbit plants. Erwinia tracheiphila migrates to the insect gut epithelium (Mitchell, 2004) and is deposited at sites of foliar feeding damage on healthy leaves through infected fecal droppings (Yao et al., 1996; Mitchell and Hanks, 2009). Bacteria migrate toward wounds when an aqueous film on the leaf surface is sufficient (Ferreira and Boley, 1992), next multiply in xylem vessels, where excrete polysaccharides, secrete enzymes that break down some of the cell wall substrates and induce xylem parenchyma cells to produce tyloses (outgrowths/ extragrouth on parenchyma cells of xylem vessels that can fall from the cells during plant stress or infection). As a result, gels and gums are formed that block vessels and reduce the upward flow of water in the xylem by up to $80 \%$. Finally, the leaves and vines wilt (Agrios, 2008). Shapiro et al. (2012) reported that E. tracheiphila alters the foliar and floral VOC emission of its plant host (Cucurbita pepo var. texana) in comparison to healthy plants. In this way, changes in plant VOCs lead to enhancement of aggregation of insect vectors on infected plants and subsequent pathogen transmission to other plants.

\section{Bacterial Wilt of Maize: Stewart's Bacterial Wilt}

Pantoea stewartii (Erwiniaceae) causes Stewart's vascular wilt and leaf blight of maize and sweet corn (Coplin et al., 2002), which is responsible for serious crop losses throughout the world (Coplin et al., 2002). This bacterium is unable to spread from plant to plant without an insect vector (Menelas et al., 2006). Several beetle species of the Chrysomelidae, Elateridae, and Scarabeidae families are vectors of P. stewartii (Table 1). In the United States, the spreading of Stewart's wilt disease is fundamentally associated with the Chaetocnema pulicaria (Chrysomelidae; Esker et al., 2006). More precisely, the incidence of the disease depends on the winter weather conditions affecting the C. pulicaria population because the severity of the disease depends on the number of insects that have survived winter (Nadarasah and Stavrinides, 2011; Bae et al., 2015). Beetles acquire bacterium during feeding on infected corn plants, harbour bacteria along the alimentary tract (foregut, midgut, hindgut; Menelas et al., 2006; Nadarasah and Stavrinides, 2011; Orlovskis et al., 2015), where bacteria remain for the entire duration of the insect's life (Nadarasah and Stavrinides, 2011). After overwintering time, beetles exit their dormancy stage and start feeding, during which they transmit the bacteria into the feeding wounds via their feces (Esker and Nutter, 2002; Menelas et al., 2006). As a result, bacteria enter the vascular tissue of corn leaves and cause disease development (Nadarasah and Stavrinides, 2011).

\section{Pantoea ananatis}

Pantoea ananatis (Erwiniaceae) can be associated with plants as an epiphyte, endophyte, pathogen, or symbiont (Lodewyckx et al., 2002; Coutinho and Venter, 2009). That bacterium can cause disease symptoms in a wide range of economically important crops (including in Cattleya sp., Musa sp., Cassia pectuta, sugarcane) or forests (Coutinho and Venter, 2009). For instance, losses of up to $100 \%$ were recorded in the cultivation of onions (Gitaitis and Gay, 1997). New reports of disease occurring on a yet unrecorded host are noted. It was established that bacteria enter plants through flowers (Hasegawa et al., 2003; McLeod et al., 2005), wounding caused by insect feeding (Wells et al., 2002; Gitaitis et al., 2003; McLeod et al., 2005; Coutinho and Venter, 2009), mechanical damages 
(Serrano, 1928), and plant-to-plant contact (Cother et al., 2004). The transmission of $P$. ananatis by insects is relatively unknown. Gitaitis et al. (2003) connected disease symptoms on onion with tobacco thrips vector. In the case of beetles, Krawczyk et al. (2020) indicated that $P$. ananatis isolated from O. melanopus was able to develop disease symptoms on wheat plants. It was also reported that $D$. virgifera virgifera is associated with $P$. ananatis (Krawczyk et al., 2021). Obtained results suggest that both beetle species can act as potential reservoirs or vectors of this pathogen.

\section{FUNGAL TRANSMISSION}

The transmission of fungi by insects occurs usually accidentally. Insects can be contaminated with the fungus or its spores during visiting infected plants, externally (for instance during walking) or internally (through feeding). Spores and mycelia adhering to insect bodies or ingested by insects are transported to healthy plant tissues (Willsey et al., 2017; Figure 2). Some of the beetles have special organs, namely mycangia, for carrying fungi (Amman, 1983).

\section{Blue Stain Fungi}

Blue stain fungi (Ophiostomataceae) are necrotrophic pathogens that are associated with various conifers and bark beetle species of the Curculionidae family (Table 1; Amman, 1983; Pan et al., 2018). Beetles vector blue stain fungi of varying virulence that penetrate the tree tissue when the insects tunnel in the phloem (Zhou et al., 2002; Masuya et al., 2003). Fungi can colonize phloem and xylem tissue away from the bark beetle tunnels, capturing tree resources (Six, 2012). The tree dies due to the girdling of both insect adults and larvae and blockage of the tree's conductive vessels by the fungus (Amman, 1983).

Interestingly, blue stain fungi can elicit tree defenses (Viiri et al., 2001; Lieutier et al., 2009; Shapiro et al., 2012) likely to the benefit of their insect host (Paine et al., 1997; Pan et al., 2018) and can be involved in the production of plant pheromones attracting the insect vectors (Zhao et al., 2015).

The economic losses caused by beetles in combination with blue stain fungi can be huge. For instance, pine shoot beetle from the genus Tomicus (T. yunnanensis, T. minor, T. brevipilosus; Table 1) destroyed 93,000 ha of economically and ecologically important conifers of Yunnan pine (Pinus yunnanensis) in Southwest China since the 1980s (Lu, 2011; Pan et al., 2018).

Leptographium wageneri can be responsible for black-stain root disease (BSRD), which can cause considerable damages in conifers forests, for instance, in Northwest America. BSRD can lead to growth reduction, chlorosis development, dark staining of the tracheids from the roots to the lower bole, and ultimately tree death (Jacobs and Wingfield, 2001). Insect vectors play a major role in the spreading of $L$. wageneri inoculums (Table 1). Fungal conidia are produced in sticky masses (conidial droplets) at the apex of stalked conidiophores, inside the galleries created by the bark beetle. Two pests of the Curculionidae family Hylastes macer and Hylastes nigrinus
(Table 1), are the most important vectors of $L$. wageneri in Douglas-fir and ponderosa pine plantations in the western United States (Schowalter, 2018). In the pines tree, L. wageneri is spread by $H$. nigrinus and by several long-snouted weevils of the Curculionidae family: e.g., Steremnius carinatus, Pissodes fasciatus (Curculionidae; Table 1).

The fungus Ophiostoma ulmi and Ophiostoma novo-ulmi cause vascular wilt disease of elm trees (Dutch elm disease, DED; Brasier, 1991), which is considered one of the most destructive diseases of the woody tree. It was estimated that O. ulmi destroyed approximately $10 \%$ of the European elm population (Brasier, 2001). Above mentioned fungi naturally spread to new hosts via root grafts, but its insect vector transmission is the most important way of dispersal (Table 1). O. ulmi and O. novo-ulmi are in a close association with the bark beetles from the genera Scolytus and Hylurgopinus (McLeod et al., 2005; Willsey et al., 2017; Table 1), that spread fungi over large areas. It has been suggested that more than $99 \%$ of the elm tree infection are caused by the fungus transmitted by the elm bark beetle. Insect adults can carry on their bodies thousands of fungal spores, which are deposited in the wounded moist tissues of the tree. It is worth mentioning that trees infected by fungus responsible for DED cause higher production of sociochemicals, which attract the insect vector Hylurgopinus rufipes (Curculionidae), which increase the efficiency of spreading this pathogen (McLeod et al., 2005; Willsey et al., 2017).

\section{OOMYCOTA}

Epitrix sp. (Chrysomelidae) are considered a serious pest of various species of plants. For instance, Epitrix tuberis is primarily associated with members of Solanaceae family, especially with potato plants (Malumphy et al., 2016). Both adults and larvae of E. tuberis are harmful to plants. It was noted that E. tuberis may enhance dispersal of the Phytophthora infestans (Peronosporacea; Leach, 1940; Table 1), causing the potato blight. Interestingly, E. tuberis can act as a multivector. The role of this insect in spreading various plant pathogens was reported in the past in the literature. It was indicated that $E$. tuberis can transmit bacteria Raltsonia solanacearum (Burkholderiaceae) responsible for potato brown rot, Streptomyces scabiei (Streptomycetaceae) causing potato scab, and potato spindle tuber viroid (PSTV, Pospiviroidae; Table 1; Leach, 1940). Generally, all species of Epitrix sp. can transmit plant pathogens that may have a negative impact on crop yield.

\section{NEMATODES TRANSMISSION}

Transmission of nematodes can take several ways including direct contact between plant roots, through contaminated tools, or insect vectors. Generally, nematodes transmitted by beetles migrate to trees through wounds caused by beetle feeding and through the oviposition slits in the bark (Agrios, 2008). Healthy plants may also become contaminated by nematodes through insect feces (Bierhals et al., 2018). 


\section{Pine Wilt}

Pine wood nematode (PWN, Bursaphelenchus xylophilus, Aphelenchoididae) is an invasive pathogen that causes pine wilt disease (PWD). Significant losses of pines caused by PWD were reported, e.g., in Japan, Korea, China, and Portugal (Cheng et al., 2013; Alves et al., 2016; Van Nguyen et al., 2017). For instance, the damaged area of PWD covered 7,829 ha in Korea, in 2008 (Han et al., 2008). It is noted that 21 species of Cerambycidae, one species of Budrestidae, and two species of Curculionidae are related to PWD worldwide (Li et al., 2020). But species of the Monochamus genus (Cerambycidae; Table 1) are considered the principal vectors of PWD (Filipiak et al., 2021). The nematode special fourth-stage dispersal juveniles are adapted to survive in the respiratory system (trachea) of beetle vectors. Nematodes enter the beetles tracheal system via openings in the beetle's exoskeleton (spiracles). Nematodes are transmitted by beetles and enter the tree through the wounds caused by beetle feeding or oviposition slits in the bark. Next, adult nematodes are produced that migrate from the cambium to the resin canals, xylem, and cortex (Agrios, 2008). PWD contributes to plant death by blocking water conductance through the xylem. The damaged tree is visited by females of beetle that lay eggs. Monochamus larvae develop in the tree cambium and borrow into the wood. When new beetles emerge, the PWDs migrate to the insect respiratory system (Mota and Vieira, 2008; Mota et al., 2009).

\section{Red Ring of Coconut Palms}

Red ring disease (RRD) is a highly lethal disease (Bierhals et al., 2018) caused by red ring nematode (RRN; Bursaphelenchus cocophilus, Aphelenchoididae), which invades parenchymal tissue in the roots, stems, leaves, and artificially infested nuts. The most characteristic infection symptom is an orange to brick-red colored ring in a cross-section of the stem. RRN causes the development of tyloses in xylem vessels blocking the upward movement of water and nutrients (Bierhals et al., 2018). Consequently, leaves become short and deformed. They wilt and die after turning color from yellow bronze to deep reddish-brown (Esser and Meredith, 1987). Due the RRD around $35 \%$ of young coconut trees in Trinidad and $80 \%$ of trees of coconut trees of one plantation in nearby Tobago died (Esser and Meredith, 1987). Transmission of nematodes to other plants can take several ways, through direct contact between infected and healthy roots, contaminated tools, or insect vectors (Bierhals et al., 2018). Red palm weevil Rhynchophorus palmarum (Curculionidae) is a host and a vector of RRN (Table 1). It is estimated that 72\% of $R$. palmarum population is associated with RRD (Esser and Meredith, 1987). Cut palm leaves exude compounds that attract $R$. palmarum. Healthy plants are primarily contaminated by nematodes through insect feces or female oviposition on the plant leaf axils (Bierhals et al., 2018). Next, nematodes penetrate the plant tissues through wounds caused by insect feeding (Bierhals et al., 2018). Larvae of weevils are being inoculated by nematodes during feeding on infected red ring tissue. RRN enters the hemocoel of weevil larvae via the gut track. In adult weevils, this nematode can be in the gut, body cavity, and ovipositor region. Infected adult weevils emerging from trees can transmit the invasive third-stage larval nematodes ready to infest a new tree (Agrios, 2008).

\section{CONSEQUENCES OF PATHOGEN TRANSMISSION BY BEETLES}

The transmission of plant pathogens can affect all the components of the pathogen - plant - beetle vector system. The components of this system are additionally affected by environmental factors and the plant protection strategies aimed to reduce the spread of pathogens and pests. In general, the consequences of these three-way interactions are manifold. The examples are listed below.

For the plant, both beetle feeding and damages caused by pathogens are harmful and can have a negative impact on the crop quantity and quality as well as plant growth and development. Sometimes damages may result in the death of the plant. Importantly, in this situation, the plant has to deal with two stressors (pathogens and beetles) at the same time, and fine-tune its defence response at the lowest possible cost of energy (Wielkopolan and Obrępalska-Stęplowska, 2016).

The microbes influence many aspects of insect host life, including adaptation to new environmental niches or plant hosts (Henry et al., 2021), which is beneficial for both insects and microorganisms. From the ecological point of view, the plant pathogens dispersal by vectors is a key factor of distribution and incidence of some plant diseases. Insect vectors may benefit from insect-associated microorganisms (Musser et al., 2003) because microbes can modulate plant defence mechanisms in favour of their insect vector (Paine et al., 1997; Wielkopolan and Obrępalska-Stęplowska, 2016; Pan et al., 2018). It was shown that insect-associated bacteria can cause that the plant defence against insects is milder. For instance, it was indicated that $O$. melanopus-associated bacteria suppressed the expression of wheat genes encoding of harmful to insects serine protease inhibitors (Wielkopolan et al., 2018). This situation might also apply to pathogens.

Vector-borne pathogens can also alter the phenotype of the plant, including its palatability and quality to enhance the aggregation of insect vectors on the infected plant (Mauck et al., 2010). For instance, larvae of $E$. varivestis grow faster on virusinfected leaf tissue. This suggests that the virus $-E$. varivestis relationship might be potentially beneficial for insects since larger insects typically have a higher reproductive potential and they are more likely to escape natural enemies, which increases the chances of transmitting pathogens (Musser et al., 2003).

\section{CONCLUSION}

Beetles with chewing mouthparts disrupt tissue continuity during feeding and wounding caused by them can constitute a point of entry to plant pathogens. This article presented examples and mechanisms of phytopathogen transmission by beetles. For a plant disease to initiate and develop, the common 
host for pest and pathogen is required as well as the synchronization between the plant development and the appearance of beetle vector and the pathogen. Climate changes may affect the spread of new alien species of beetle and pathogens to new areas, as a result, new trophic relationships between them can be established. There are still significant gaps in our understanding of beetle-plant-pathogen interactions and their consequence for disease incidence and pathogen spread. Therefore, the main challenges for future research are to understand the mechanism of (a) the acquisition and transmission of the plant pathogens by the insect vectors, (b) plant defense response against insects and associated with them pathogens, and (c) the impact of the pathogen on its insect vector. Research at the molecular level and metagenomic studies may provide a lot of valuable information about three-trophic interactions. Obtained knowledge should provide a more holistic understanding of disease dynamics and will allow for guiding effective monitoring and developing effective tools to limit pathogen transmission and disease incidence.

\section{REFERENCES}

Acevedo, F. E., Peiffer, M., Tan, C.-W., Stanley, B. A., Stanley, A., Wang, J., et al. (2017). Fall armyworm-associated gut bacteria modulate plant defense responses. Mol. Plant-Microbe Interact. 30, 127-137. doi: 10.1094/MPMI-11-16-0240-R

Agrios, G. N. (2008). "Transmission of plant diseases by insects," in Encyclopedia of Entomology. ed. J. L. Capinera (Dordrecht: Springer Netherlands), 3853-3885.

Akbulut, S., Keten, A., and Stamps, W. T. (2008). Population dynamics of Monochamus galloprovincialis Olivier (Coleoptera: Cerambycidae) in two pine species under laboratory conditions. J. Pest. Sci. 81, 115-121. doi: 10.1007/s10340-008-0195-z

Akbulut, S., and Stamps, W. T. (2012). Insect vectors of the pinewood nematode: a review of the biology and ecology of Monochamus species. For. Pathol. 42, 89-99. doi: 10.1111/j.1439-0329.2011.00733.x

Alves, M., Pereira, A., Matos, P., Henriques, J., Vicente, C., Aikawa, T., et al. (2016). Bacterial community associated to the pine wilt disease insect vectors Monochamus galloprovincialis and Monochamus alternatus. Sci. Rep. 6, 1-12. doi: $10.1038 /$ srep23908

Amman, G. D. (1983). Mountain Pine Beetle Dynamics in Lodgepole Pine Forests: Population Dynamics. US Department of Agriculture, Forest Service, Intermountain Forest and Range.

Bae, C., Han, S. W., Song, Y. R., Kim, B. Y., Lee, H. J., Lee, J. M., et al. (2015). Infection processes of xylem-colonizing pathogenic bacteria: possible explanations for the scarcity of qualitative disease resistance genes against them in crops. Theor. Appl. Genet. 128, 1219-1229. doi: 10.1007/s00122-015-2521-1

Bergdahl, D. R., Halik, S., Tomminen, J., and Akar, H. (1991). Frequency of infestation of Monochamus notatus and M. scutellatus by Bursaphelenchus xylophilus in Vermont. Phytopathology 81:120.

Bhat, A. I., and Rao, G. P. (2020). "Virus transmission through pollen," in Characterization of Plant Viruses (New York: Humana Press), 61-64.

Bierhals, A. N., Da Silva Torres, D., Duarte, A. G., and Marafon, A. C. (2018). Persistence of the red ring nematode in the roots and in the rhizosphere of recently eradicated coconut palms. Semin. Agrar. 39, 487-496. doi: 10.5433/1679-0359.2018v39n2p487

Brasier, C. M. (1991). Ophiostoma novo-ulmi sp. nov., causative agent of current Dutch elm disease pandemics. Mycopathologia 115, 151-161. doi: 10.1007/ BF00462219

Brasier, C. M. (2001). Rapid evolution of introduced plant pathogens via interspecific hybridization. Bioscience 51, 123-133. doi: 10.1641/0006-3568(2001)051[0123:RE OIPP]2.0.CO;2

Catherall, P. L. (1987). Effects of barley yellow dwarf and ryegrass mosaic viruses alone and in combination on the productivity of perennial and

\section{AUTHOR CONTRIBUTIONS}

AO-S and BW: conceptualization, literature review, data analysis, and writing - original draft preparation. BW, MJ, and AO-S: writing - review and editing. AO-S: funding acquisition. All authors contributed to the article and approved the submitted version.

\section{FUNDING}

This work was supported by the Polish National Science Centre within the UMO-2016/23/B/NZ9/03503 agreement.

\section{ACKNOWLEDGMENTS}

The authors would like to thank Irena Rabęda for the help in figures preparation. Part of figures' elements was created with https://www.freepik.com/.

Italian ryegrasses. Plant Pathol. 36, 73-78. doi: 10.1111/j.1365-3059.1987. tb02179.x

Cheng, X. Y., Tian, X. L., Wang, Y. S., Lin, R. M., Mao, Z. C., Chen, N., et al. (2013). Metagenomic analysis of the pinewood nematode microbiome reveals a symbiotic relationship critical for xenobiotics degradation. Sci. Rep. 3, 1-10. doi: 10.1038/srep01869

Chesnais, Q., Mauck, K. E., Bogaert, F., Bamière, A., Catterou, M., Spicher, F., et al. (2019). Virus effects on plant quality and vector behavior are species specific and do not depend on host physiological phenotype. J. Pest. Sci. 92, 791-804. doi: 10.1007/s10340-019-01082-z

Chesnais, Q., Vidal, G. C., Coquelle, R., Yvon, M., Mauck, K., Brault, V., et al. (2020). Post-acquisition effects of viruses on vector behavior are important components of manipulation strategies. Oecologia 194, 429-440. doi: 10.1007/ s00442-020-04763-0

Chung, S. H., Rosa, C., Scully, E. D., Peiffer, M., Tooker, J. F., Hoover, K., et al. (2013). Herbivore exploits orally secreted bacteria to suppress plant defenses. Proc. Natl. Acad. Sci. U. S. A. 110, 15728-15733. doi: 10.1073/ pnas. 1308867110

Coplin, D. L., Majerczak, D. R., Zhang, Y., Kim, W. S., Jock, S., and Geider, K. (2002). Identification of Pantoea stewartii subsp. stewartii by PCR and strain differentiation by PFGE. Plant Dis. 86, 304-311. doi: 10.1094/PDIS.2002.86.3.304

Cother, E. J., Reinke, R., McKenzie, C., Lanoiselet, V. M., and Noble, D. H. (2004). An unusual stem necrosis of rice caused by Pantoea ananas and the first record of this pathogen on rice in Australia. Australas. Plant Pathol. 33, 495-503. doi: 10.1071/AP04053

Coutinho, T. A., and Venter, S. N. (2009). Pantoea ananatis: an unconventional plant pathogen. Mol. Plant Pathol. 10, 325-335. doi: 10.1111/j. 1364-3703.2009.00542.x

Du, D., Winsor, J. A., Smith, M., DeNicco, A., and Stephenson, A. G. (2008). Resistance and tolerance to herbivory changes with inbreeding and ontogeny in a wild gourd (Cucurbitaceae). Am. J. Bot. 95, 84-92. doi: 10.3732/ajb.95.1.84

EPPO (1997). Data sheets on quarantine pests: Pantoea stewartii subsp. stewartii. Quarantine Pests for Europe, 2nd, EPPO A2 list: No. 54, Prepared by CABI and EPPO for the EU under Contract 90/399003.

Esker, P. D., Harri, J., Dixon, P. M., and Nutter, F. W. (2006). Comparison of models for forecasting of Stewart's disease of corn in Iowa. Plant Dis. 90, 1353-1357. doi: 10.1094/PD-90-1353

Esker, P. D., and Nutter, F. W. Jr. (2002). Assessing the risk of Stewart's disease of corn through improved knowledge of the role of the corn flea beetle vector. Phytopathology 92, 668-670. doi: 10.1094/PHYTO.2002.92.6.668

Esser, R. P., and Meredith, J. A. (1987). Red Ring Nematodes. Nematology Circular No.141, Florida Department of Agriculture and Consumer Services, Division of Plant Industry, Gainesville, FL, USA. 
Faccoli, M., and Battisti, A. (1997). "Observations on the transmission of Ophiostoma ulmi by the smaller elm bark beetles (Scolytus spp.)." in Proceedings of a IUFRO Meeting: Integrating Cultural Tactics Into the Management of Bark Beetles and Reforestation Pests; September 1-3, 1996; Vallombrosa, Italy, 172-176.

Fan, Y., Groden, E., and Drummond, F. A. (1992). Temperature-dependent development of Mexican bean beetle (Coleoptera: Coccinellidae) under constant and variable temperatures. J. Econ. Entomol. 85, 1762-1770. doi: $10.1093 /$ jee/85.5.1762

Fereres, A., and Raccah, B. (2015). "Plant virus transmission by insects," in The Major Transmission Modes. eLS, 1-12.

Ferreira, S. A., and Boley, R. A. (1992). Erwinia tracheiphila Bacterial Wilt of Cucurbits. Department of Plant Pathology, CTAHR, University of Hawaii at Monoa.

Filipiak, A., Malewski, T., Matczyńska, E., and Tomalak, M. (2021). Molecular variation among virulent and avirulent strains of the quarantine nematode Bursaphelenchus xylophilus. Mol. Gen. Genomics. 296, 259-269. doi: 10.1007/ s00438-020-01739-w

Fulton, J. P., and Scott, H. A. (1974). Virus vectoring efficiencies of two species of leaf-feeding beetles. Proc. Amer. Phytopath. Soc. 1:159.

Fulton, J. P., and Scott, H. A. (1977). Bean rugose mosaic and related viruses and their transmission by beetles. Fitopatol. Bras. 2, 9-16.

Gedling, C. R., Smith, C. M., LeMoine, C. M. R., and Cassone, B. J. (2018). The Mexican bean beetle (Epilachna varivestis) regurgitome and insights into beetle-borne virus specificity. PLoS One 13:e0192003. doi: 10.1371/ journal.pone. 0192003

Gergerich, R. C. (1999). "Comoviruses: bean pod mottle comovirus," in Compendium of Soybean Diseases. 4th Edn. eds. G. L. Hartman, J. B. Sinclair and J. C. Rupe (St. Paul, Minnesota: APS Press), 61-62.

Gergerich, R. C. (2001). "Mechanism of virus transmission by leaf-feeding beetles," in Virus-Insect-Plant Interactions (Elsevier), 133-142.

Gergerich, R. C., and Scott, H. A. (1988). Evidence that virus translocation and virus infection of non-wounded cells are associated with transmissibility by leaf-feeding beetles. J. Gen. Virol. 69, 2935-2938. doi: 10.1099/0022-1317-69-11-2935

Gergerich, R. C., and Scott, H. A. (1991). "Determinants in the specificity of virus transmission by leaf-feeding beetles," in Advances in Disease Vector Research (New York, NY: Springer), 1-13.

Gergerich, R. C., and Scott, H. A. (1996). "Comoviruses: transmission, epidemiology, and control," in The Plant Viruses (Boston, MA: Springer), 77-98.

Ghosh, A., Chakrabarti, S., Mandal, B., and Kumar, N. K. K. (2017). "Aphids as vectors of the plant viruses in India," in A Century of Plant Virology in India (Singapore: Springer), 515-536.

Giblin-Davis, R. M., Faleiro, J. R., Jacas, J. A., Peña, J. E., and Vidyasagar, P. S. P. V. (2013). "Biology and management of the red palm weevil, Rhynchophorus ferrugineus," in Potential Invasive Pests of Agricultural Crops. ed. J. E. Peña, $1-34$.

Giesler, L. J., Ghabrial, S. A., Hunt, T. E., and Hill, J. H. (2002). Bean pod mottle virus: a threat to U.S. soybean production. Plant Dis. 86, 1280-1289. doi: 10.1094/PDIS.2002.86.12.1280

Gitaitis, R. D., and Gay, J. D. (1997). First report of a leaf blight, seed stalk rot, and bulb decay of onion by Pantoea ananas in Georgia. Plant Dis. 81:1096. doi: 10.1094/PDIS.1997.81.9.1096C

Gitaitis, R. D., Walcott, R. R., Wells, M. L., Diaz Perez, J. C., and Sanders, F. H. (2003). Transmission of Pantoea ananatis, causal agent of center rot of onion, by tobacco thrips, Frankliniella fusca. Plant Dis. 87, 675-678. doi: 10.1094/PDIS.2003.87.6.675

Gurung, K., Wertheim, B., and Falcao Salles, J. (2019). The microbiome of pest insects: it is not just bacteria. Entomol. Exp. Appl. 167, 156-170. doi: $10.1111 /$ eea. 12768

Hammer, T. J., Janzen, D. H., Hallwachs, W., Jaffe, S. P., and Fierer, N. (2017). Caterpillars lack a resident gut microbiome. Proc. Natl. Acad. Sci. U. S. A. 114, 9641-9646. doi: 10.1073/pnas.1707186114

Han, H., Chung, Y.-J., and Shin, S.-C. (2008). First report of pine wilt disease on Pinus koraiensis in Korea. Plant Dis. 92:1251. doi: 10.1094/PDIS-92-8-1251A

Haran, J., Rousselet, J., Tellez, D., Roques, A., and Roux, G. (2018). Phylogeography of Monochamus galloprovincialis, the European vector of the pinewood nematode. J. Pest. Sci. 91, 247-257. doi: 10.1007/ s10340-017-0878-4
Hasegawa, M., Azegami, K., Yoshida, H., and Otani, H. (2003). Behavior of Erwinia ananas transformed with bioluminescence genes on rice plants. J. Gen. Plant Pathol. 69, 267-270. doi: 10.1007/s10327-003-0046-y

Heard, T. A. (1999). "Concepts in insect host-plant selection behavior and their application to host specificity testing." in Host Specificity of Exotic Arthropod Biological Control Agents: The Biological Basis for Improvement in Safety, Proceedings of Session: X International Symposium on Biological Control of Weed, 1-10.

Henry, L. P., Bruijning, M., Forsberg, S. K., and Ayroles, J. F. (2021). The microbiome extends host evolutionary potential. Nat. Commun. 12:5141. doi: $10.1038 / \mathrm{s} 41467-021-25315-\mathrm{x}$

Hopkins, J. D., and Mueller, A. J. (1984). Effect of bean pod mottle virus on soybean yield. J. Econ. Entomol. 77, 943-947. doi: 10.1093/jee/77.4.943

Jacobs, K., and Wingfield, M. J. (2001). Species: Tree Pathogens, Insect Associates, and Agents of Blue-Stain. Minnesota: American Phytopathological Society.

Jones, D. R. (2003). Plant viruses transmitted by whiteflies. Eur. J. Plant Pathol. 109, 195-219. doi: 10.1023/A:1022846630513

Krawczyk, K., Foryś, J., Nakonieczny, M., Tarnawska, M., and Bereś, P. K. (2021). Transmission of Pantoea ananatis, the causal agent of leaf spot disease of maize (Zea mays), by western corn rootworm (Diabrotica virgifera virgifera LeConte). Crop Prot. 141:105431. doi: 10.1016/j.cropro.2020.105431

Krawczyk, K., Wielkopolan, B., and Obrępalska-Stęplowska, A. (2020). Pantoea ananatis, a new bacterial pathogen affecting wheat plants (Triticum 1.) in Poland. Pathogens 9:1079. doi: 10.3390/pathogens9121079

Leach, J. G. (1940). Insect Transmission of Plant Diseases. New York and London: McGraw-Hill Book Co., Inc.

Li, M., Li, H., Sheng, R. C., Sun, H., Sun, S. H., and Chen, F. M. (2020). The first record of Monochamus saltuarius (Coleoptera; Cerambycidae) as vector of Bursaphelenchus xylophilus and its new potential hosts in China. Insects 11:636. doi: 10.3390/insects11090636

Lieutier, F., Yart, A., and Salle, A. (2009). Stimulation of tree defenses by ophiostomatoid fungi can explain attack success of bark beetles on conifers. Ann. For. Sci. 66:801. doi: 10.1051/forest $/ 2009066$

Linit, M. J. (1988). Nemtaode-vector relationships in the pine wilt disease system. J. Nematol. 20:227.

Lodewyckx, C., Vangronsveld, J., Porteous, F., Moore, E. R. B., Taghavi, S., Mezgeay, M., et al. (2002). Endophytic bacteria and their potential applications. Crit. Rev. Plant Sci. 21, 583-606. doi: 10.1080/0735-260291044377

Lu, J. (2011). On the Occurrence, Distribution and Damage Mechanisms of Four Tomicus Species in Southwestern China. Doctoral dissertation, Ph. D. dissertation (Kunming, Yunnan, China: School of Life Sciences, Yunnan University).

Luzzi, M. A., Wilkinson, R. C., and Tarjan, A. C. (1984). Transmission of the pinewood nematode, Bursaphelenchus xylophilus, to slash pine trees and log bolts by a Cerambycid beetle, Monochamus titillator, in Florida. J. Nematol. $16,37-40$.

Malumphy, C., Everatt, M., Giltrap, N., and Eyre, D. (2016). Potato flea beetles Epitrix species. Pest Factsheet, DEFRA.

Mamiya, Y., and Enda, N. (1972). Transmission of Bursaphelenchus lignicolus (Nematoda: Aphelenchoididae) by Monochamus alternatus (Coleoptera: Cerambycidae). Nematologica 18, 159-162. doi: 10.1163/187529272X00395

Mann, R. S., Ali, J. G., Hermann, S. L., Tiwari, S., Pelz-Stelinski, K. S., Alborn, H. T., et al. (2012). Induced release of a plant-defense volatile "deceptively" attracts insect vectors to plants infected with a bacterial pathogen. PLoS Pathog. 8:e1002610. doi: 10.1371/journal.ppat.1002610

Mason, C. J., Jones, A. G., and Felton, G. W. (2019). Co-option of microbial associates by insects and their impact on plant-folivore interactions. Plant Cell Environ. 42, 1078-1086. doi: 10.1111/pce.13430

Masuya, H., Kaneko, S., and Yamaoka, Y. (2003). Comparative virulence of blue-stain fungi isolated from Japanese red pine. J. For. Res. 8, 83-88. doi: $10.1007 / \mathrm{s} 103100300009$

Mauck, K. E., Chesnais, Q., and Shapiro, L. R. (2018). Evolutionary determinants of host and vector manipulation by plant viruses. Adv. Virus Res. 101 189-250. doi: 10.1016/bs.aivir.2018.02.007

Mauck, K. E., De Moraes, C. M., and Mescher, M. C. (2010). Deceptive chemical signals induced by a plant virus attract insect vectors to inferior hosts. Proc. Natl. Acad. Sci. U. S. A. 107, 3600-3605. doi: 10.1073/pnas.0907191107

Mauck, K. E., De Moraes, C. M., and Mescher, M. C. (2014). Biochemical and physiological mechanisms underlying effects of cucumber mosaic virus 
on host-plant traits that mediate transmission by aphid vectors. Plant Cell Environ. 37, 1427-1439. doi: 10.1111/pce.12249

McLeod, G., Gries, R., Von Reuß, S. H., Rahe, J. E., McIntosh, R., König, W. A., et al. (2005). The pathogen causing Dutch elm disease makes host trees attract insect vectors. Proc. R. Soc. B Biol. Sci. 272, 2499-2503. doi: 10.1098/ rspb.2005.3202

Menelas, B., Block, C. C., Esker, P. D., and Nutter, F. W. (2006). Quantifying the feeding periods required by corn flea beetles to acquire and transmit Pantoea stewartii. Plant Dis. 90, 319-324. doi: 10.1094/PD-90-0319

Mitchell, P. L. (2004). Heteroptera as vectors of plant pathogens. Neotrop. Entomol. 33, 519-545. doi: 10.1590/S1519-566X2004000500001

Mitchell, R. F., and Hanks, L. M. (2009). Insect frass as a pathway for transmission of bacterial wilt of cucurbits. Environ. Entomol. 38, 395-403. doi: $10.1603 / 022.038 .0212$

Mota, M. M., Futai, K., and Vieira, P. (2009). "Pine wilt disease and the pinewood nematode, Bursaphelenchus xylophilus," in Integrated Management of Fruit Crops Nematodes (Dordrecht: Springer), 253-274.

Mota, M., and Vieira, P. (2008). Pine wilt disease: a worldwide threat to forest ecosystems. Nematology 11, 315-316. doi: 10.1163/156854109X404553

Musser, R. O., Hum-Musser, S. M., Felton, G. W., and Gergerich, R. C. (2003). Increased larval growth and preference for virus-infected leaves by the Mexican bean beetle, Epilachna varivestis Mulsant, a plant virus vector. J. Insect Behav. 16, 247-256. doi: 10.1023/A:1023919902976

Nadarasah, G., and Stavrinides, J. (2011). Insects as alternative hosts for phytopathogenic bacteria. FEMS Microbiol. Rev. 35, 555-575. doi: 10.1111/j. 1574-6976.2011.00264.x

Nakamura, H., and Chavez, F. G. (2007). Report of the Investigation on Epilachna varivestis Defoliation in Guatemala High Land. Bulletin Shinshu University Alpine Field Center.

Nault, L. R. (1978). Transmission of maize chlorotic mottle virus by chrysomelid beetles. Phytopathology 68:1071. doi: 10.1094/Phyto-68-1071

Orlovskis, Z., Canale, M. C., Thole, V., Pecher, P., Lopes, J. R., and Hogenhout, S. A. (2015). Insect-borne plant pathogenic bacteria: getting a ride goes beyond physical contact. Curr. Opin. Insect Sci. 9, 16-23. doi: 10.1016/j.cois.2015.04.007

Paine, T. D., Raffa, K. F., and Harrington, T. C. (1997). Interaction among Scolytid bark beetles, their associated fungi, and live host conifers. Annu. Rev. Entomol. 42, 179-206. doi: 10.1146/annurev.ento.42.1.179

Pajares, J. A., Álvarez, G., Hall, D. R., Ibarra, N., Hoch, G., Halbig, P., et al. (2017). Attractants for management of the pine sawyer beetle Monochamus sutor, a potential vector of Bursaphelenchus xylophilus. J. Appl. Entomol. 141, 97-111. doi: 10.1111/jen.12320

Pan, Y., Zhao, T., Krokene, P., Yu, Z. F., Qiao, M., Lu, J., et al. (2018). Bark beetle-associated blue-stain fungi increase antioxidant enzyme activities and monoterpene concentrations in pinus yunnanensis. Front. Plant Sci. 871:1731. doi: $10.3389 /$ fpls.2018.01731

Perilla-Henao, L. M., and Casteel, C. L. (2016). Vector-borne bacterial plant pathogens: interactions with hemipteran insects and plants. Front. Plant Sci. 7:1163. doi: $10.3389 /$ fpls.2016.01163

Raccah, B., and Fereres, A. (2009). "Plant virus transmission by insects," in Encyclopedia of Life Sciences (ELS). Chichester: John Wiley \& Sons, Ltd.

Rand, F. V., and Enlows, E. M. A. (1916). Transmission and control of bacterial wilt of cucurbits. J. Agric. Res. 6, 417-434.

Rojas, E. S., Gleason, M. L., Batzer, J. C., and Duffy, M. (2011). Feasibility of delaying removal of row covers to suppress bacterial wilt of muskmelon (Cucumis melo). Plant Dis. 95, 729-734. doi: 10.1094/PDIS-11-10-0788

Salaau Rojas, E. (2013). Bacterial wilt of cucurbits: ecology, genetics, and management. Graduate Theses and Dissertations. 13387.

Sasu, M. A., Seidl-Adams, I., Wall, K., Winsor, J. A., and Stephenson, A. G. (2010). Floral transmission of Erwinia tracheiphila by cucumber beetles in a wild cucurbita pepo. Environ. Entomol. 39, 140-148. doi: 10.1603/EN09190

Sato, H., Sakuyama, T., and Kobayashi, M. (1987). Transmission of Bursaphelenchus xylophilus (Steiner et Buhrer) Nickle (Nematoda, Aphelenchoididae) by Monochamus saltuarius (Gebler) (Coleoptera, Cerambycidae). J. Jpn. Soc. 69, 492-496.

Schowalter, T. D. (2018). Biology and management of root-feeding beetles (Coleoptera: Curculionidae) in north American conifer forests and plantations. J. Integr. Pest Manag. 9, 1-8. doi: 10.1093/jipm/pmy005

Scott, H. A., and Fulton, J. P. (1978). Comparison of the relationships of southern bean mosaic virus and the cowpea strain of tobacco mosaic virus with the bean leaf beetle. Virology 84, 207-209. doi: 10.1016/00426822(78)90235-0

Scott, H. A., and Phatak, H. C. (1979). Properties of blackgram mottle virus. Phytopathology 69, 346-348. doi: 10.1094/Phyto-69-346

Serrano, F. B. (1928). Bacterial fruitlet brown-rot of pineapple in the Philippines. Philipp. J. Sci. 36, 271-305.

Shapiro, L., De Moraes, C. M., Stephenson, A. G., and Mescher, M. C. (2012). Pathogen effects on vegetative and floral odours mediate vector attraction and host exposure in a complex pathosystem. Ecol. Lett. 15, 1430-1438. doi: $10.1111 /$ ele. 12001

Shapiro, L. R., Seidl-Adams, I., De Moraes, C. M., Stephenson, A. G., and Mescher, M. C. (2014). Dynamics of short- and long-term association between a bacterial plant pathogen and its arthropod vector. Sci. Rep. 4:4155. doi: $10.1038 /$ srep 04155

Six, D. L. (2012). Ecological and evolutionary determinants of bark beetle: fungus symbioses. Insects 3, 339-366. doi: 10.3390/insects3010339

Smith, C. M., Gedling, C. R., Wiebe, K. F., and Cassone, B. J. (2017). A sweet story: bean pod mottle virus transmission dynamics by Mexican bean beetles (Epilachna varivestis). Genome Biol. Evol. 9, 714-725. doi: 10.1093/gbe/evx033

Stephenson, A. G., Leyshon, B., Travers, S. E., Hayes, C. N., and Winsor, J. A. (2004). Interrelationships among inbreeding, herbivory, and disease on reproduction in a wild gourd. Ecology 85, 3023-3034. doi: 10.1890/04-0005

Togashi, K., Taga, Y., Iguchi, K., and Aikawa, T. (2008). Bursaphelenchus mucronatus (Nematoda: Aphelenchoididae) vectored by Monochamus urussovi (Coleoptera: Cerambycidae) in Hokkaido, Japan. J. For. Res. 13, 127-131. doi: 10.1007/s10310-007-0057-1

Toussaint, V., Ciotola, M., Cadieux, M., Racette, G., Duceppe, M. O., and Mimee, B. (2013). "Identification and temporal distribution of potential insect vectors of Erwinia tracheiphila, the causal agent of bacterial wilt of cucurbits," in Phytopathology. Vol. 103. USA: American Phytopathological Society, 147.

Van Nguyen, T., Park, Y. S., Jeoung, C. S., Choi, W. I., Kim, Y. K., Jung, I. H., et al. (2017). Spatially explicit model applied to pine wilt disease dispersal based on host plant infestation. Ecol. Model. 353, 54-62. doi: 10.1016/j. ecolmodel.2016.10.022

Viiri, H., Annila, E., Kitunen, V., and Niemelä, P. (2001). Induced responses in stilbenes and terpenes in fertilized Norway spruce after inoculation with blue-stain fungus, Ceratocystis polonica. Trees-Struct. Funct. 15, 112-122. doi: $10.1007 / \mathrm{s} 004680000082$

Webber, J. F. (1990). Relative effectiveness of Scolytus scolytus, S. multistriatus and S. kirschi as vectors of Dutch elm disease. Eur. J. For. Pathol. 20, 184-192. doi: 10.1111/j.1439-0329.1990.tb01129.x

Wells, M. L., Gitaitis, R. D., and Sanders, F. H. (2002). Association of tobacco thrips, Frankliniella fusca (Thysanoptera: Thripidae) with two species of bacteria of the genus Pantoea. Ann. Entomol. Soc. Am. 95, 719-723. doi: 10.1603/0013-8746(2002)095[0719:AOTTFF]2.0.CO;2

Wielkopolan, B., Krawczyk, K., and Obrępalska-Stęplowska, A. (2018). Gene expression of serine and cysteine proteinase inhibitors during cereal leaf beetle larvae feeding on wheat: the role of insect-associated microorganisms. Arthropod Plant Interact. 12, 601-612. doi: 10.1007/s11829-018-9608-y

Wielkopolan, B., and Obrępalska-Stęplowska, A. (2016). Three-way interaction among plants, bacteria, and coleopteran insects. Planta 244, 313-332. doi: 10.1007/s00425-016-2543-1

Willsey, T., Chatterton, S., and Cárcamo, H. (2017). Interactions of root-feeding insects with fungal and oomycete plant pathogens. Front. Plant Sci. 8:1764. doi: $10.3389 /$ fpls.2017.01764

Wingfield, M. J., and Blanchette, R. A. (1983). The pine-wood nematode, Bursaphelenchus xylophilus, in Minnesota and Wisconsin: insect associates and transmission studies. Can. J. For. Res. 13, 1068-1076. doi: 10.1139/x83-143

Witcosky, J. J., Schowalter, T. D., and Hansen, E. M. (1986). Hylastes nigrinus (Coleoptera: Scolytidae), Pissodes fasciatus, and Steremnius carinatus (Coleoptera: Curculionidae) as vectors of black-stain root disease of Douglas-fir. Environ. Entomol. 15, 1090-1095. doi: 10.1093/ee/15.5.1090

Yao, C., Zehnder, G., Bauske, E., and Kloepper, J. (1996). Relationship between cucumber beetle (Coleoptera: Chrysomelidae) density and incidence of bacterial wilt of cucurbits. J. Econ. Entomol. 89, 510-514. doi: 10.1093/jee/89.2.510

Zhao, T., Axelsson, K., Krokene, P., and Borg-Karlson, A. K. (2015). Fungal symbionts of the spruce bark beetle synthesize the beetle aggregation pheromone 2-methyl-3-buten-2-ol. J. Chem. Ecol. 41, 848-852. doi: 10.1007/ s10886-015-0617-3 
Zhao, T., Kandasamy, D., Krokene, P., Chen, J., Gershenzon, J., and Hammerbacher, A. (2019). Fungal associates of the tree-killing bark beetle, Ips typographus, vary in virulence, ability to degrade conifer phenolics and influence bark beetle tunneling behavior. Fungal Ecol. 38, 71-79. doi: 10.1016/j. funeco.2018.06.003

Zhou, X. D., De Beer, Z. W., Wingfield, B. D., and Wingfield, M. J. (2002). Infection sequence and pathogenicity of Ophiostoma ips, Leptographium serpens and L. lundbergii to pines in South Africa. Fungal Divers. 10, 229-240.

Conflict of Interest: The authors declare that the research was conducted in the absence of any commercial or financial relationships that could be construed as a potential conflict of interest.
Publisher's Note: All claims expressed in this article are solely those of the authors and do not necessarily represent those of their affiliated organizations, or those of the publisher, the editors and the reviewers. Any product that may be evaluated in this article, or claim that may be made by its manufacturer, is not guaranteed or endorsed by the publisher.

Copyright (C) 2021 Wielkopolan, Jakubowska and Obrępalska-Steplowska. This is an open-access article distributed under the terms of the Creative Commons Attribution License (CC BY). The use, distribution or reproduction in other forums is permitted, provided the original author(s) and the copyright owner(s) are credited and that the original publication in this journal is cited, in accordance with accepted academic practice. No use, distribution or reproduction is permitted which does not comply with these terms. 